\title{
Distance exercised during submaximal training on race winnings for Thoroughbred racehorses
}

\author{
Distância percorrida durante treinamento submáximo sobre rendimentos \\ de cavalos de corrida da raça Puro Sangue Inglês
}

\author{
Carolina Berkman ${ }^{\mathrm{I}}$ Luisa Gouvea Teixeira" ${ }^{\mathrm{II}}$ Marsel Carvalho Pereira ${ }^{\mathrm{III}}$ \\ Rita de Cássia de Lima Sampaio" Nara Saraiva Bernardi ${ }^{\text {II }}$ \\ José Correia de Lacerda NetoII Antonio de Queiroz Neto ${ }^{\mathrm{I}}$ Guilherme de Camargo Ferraz $^{\mathrm{I}}$
}

\section{ABSTRACT}

Evaluations of the physical fitness of Thoroughbred racehorses have been correlated with race earnings, but few reports exist about the influence of the distance exercised during training on both physical conditioning indices and financial productivity. During one training season sixteen claiming Thoroughbred horses were subjected to submaximal training and monitored by a global positioning system (GPS) coupled to a heart rate monitor. After initial and single monitoring, the horses were distributed into two groups of eight individuals each; one group exercised short distances (SD) between 1600 and $1900 \mathrm{~m}$, while the other exercised long distances (LD) between 2000 and $2350 \mathrm{~m}$. The duration (min) and mean and maximal velocities $\left(\mathrm{ms}^{-1}\right)$ attained during each session were determined, as well as the difference in distances exercised $(m)$ between official races and each training session. Blood lactate concentration ([LA]) during recovery was also determined. Student's t-test was used for a non-paired analysis, with $P \leq 0.05$ considered significant. The winnings (USD) of each horse were correlated with the peak heart rate $\left(H R_{\text {peal }}\right)$ attained during the training session. The distances exercised in the training sessions were greater in relation to the official races distances by $24.7 \%$ and $40 \%$ for $S D$ and $L D$, respectively. Lactatemia did not differ between the groups. The HR $R_{\text {peak }}$ obtained during the training session was lower in LD group. The velocity at which the heart rate reached $200 \mathrm{bpm}\left(V_{200}\right)$ was higher in $L D$ group. There was a moderate correlation $(r=0.42)$ between the highest winnings and lowest $H R_{\text {peak }}$. The horses that ran longer distances during their submaximal training session had better cardiac conditioning and tendency to increase financial productivity.

Key words: horse, distance exercised, heart rate, lactate, race performance, race earnings.

\section{RESUMO}

Avaliações da aptidão fisica de cavalos Puro Sangue Inglês (PSI) têm sido correlacionadas com o ganho financeiro, mas a influência da distância percorrida durante o treinamento, tanto sobre índices de condicionamento fisico como na produtividade financeira tem sido pouco relatada. Monitoraram-se, por meio de global positioning system (GPS) acoplado a frequencimetro, numa temporada de treinamento, dezesseis equinos da raça PSI, de uma mesma categoria, submetidos a treinamento submáximo. Após o monitoramento inicial e único de uma sessão de treino, os equinos foram distribuidos em dois grupos de oito componentes (DC e DL) diferenciados de acordo com a distância percorrida durante cada sessão de treino, sendo DC para distância curta e $D L$ para distância longa. Dessa maneira, $D C$ e $D L$ percorreram distâncias entre 1600-1900 e 2000-2350 metros, respectivamente. Determinaram-se o tempo e as velocidades médias e máximas atingidas $\left(m \mathrm{~s}^{-1}\right)$, bem como a diferença entre as distâncias percorridas (m) entre as corridas oficiais e as sessões. A produção de lactato sanguineo durante a recuperação foi quantificada. Empregou-se teste $t$ de student para análise não pareada, sendo $P \leq 0,05$. Correlacionaram-se os ganhos financeiros (USD) de cada cavalo com afrequência cardiaca de pico $\left(F C_{\text {pico }}\right)$ atingidas durante as sessões. As distâncias percorridas nos treinos foram maiores em relação às corridas oficiais em $24,7 \%$ e $40 \%$ para DC e DL, respectivamente. A lactatemia não diferiu entre os grupos. A frequência cardíaca de pico $\left(F C_{\text {pico }}\right)$ obtida durante as sessões foi menor para o grupo $D L$. A velocidade que a frequência cardiaca atingiu 200 bpm $\left(V_{200}\right)$ foi maior para DL. Houve correlação moderada entre os maiores ganhos financeiros e menores $F C_{\text {pie }}$ Os cavalos que treinaram maiores distâncias durante sessốes de treinamento submáximo tiveram melhor condicionamento cardiaco e maior produtividade financeira.

'Laboratório de Farmacologia e Fisiologia do Exercício Equino (LAFEQ), Departamento de Morfologia e Fisiologia Animal, Faculdades de Ciências Agrárias e Veterinárias (FCAV), Universidade Estadual Paulista (UNESP), Campus, 14884-900, Jaboticabal, SP, Brasil. E-mail: gferraz@fcav.unesp.br. "Corresponding author.

"Departamento de Clínica e Cirurgia Veterinária, FCAV, UNESP, Jaboticabal, SP, Brasil.

II'Universidade Federal do Mato Grosso (UFMT), Sinop, MT, Brasil. 
Palavras-chave: cavalo, distância percorrida, frequência cardíaca, lactato, desempenho, rendimentos de corrida.

\section{INTRODUCTION}

Studies performed in field conditions investigate the exercise intensity and the physiological demands for horses participating in various equestrian sports, and this information serves as a basis for the development of rational training programs (ROGERS et al., 2007).

Differences in the degree of conditioning and the efficacy of the training between individuals or groups of horses can be determined by measuring the changes in biochemical variables such as the concentration of blood lactate ([LA]) and cardiovascular variables such as heart rate (HR) (EVANS, 2007). These two physiological variables, along with velocity measurements from the global positioning system (GPS) to estimate race intensity, have become important tools for the evaluation of conditioning in race horses in field conditions (VERMEULEN \& EVANS, 2006). Using GPS for the measurement of race horse velocity is an objective, safe and non-invasive evaluation, that allows to differentiate horses with varying degrees of conditioning, and it should be used along with the variable distance exercised (DE), to prescribe training regimens (FONSECA et al., 2010). Along this line, few studies have evaluated possible influence of $\mathrm{DE}$ on the indices that measure metabolic and cardiovascular fitness during exercise.

From a physiological point of view, aerobic capacity during exercise is related to cardiac output, as demonstrated by the classic Fick equation $\left[\dot{V} \mathrm{O}_{2}=\dot{Q} \mathrm{x}\right.$ $\left.\left(\mathrm{a}-\mathrm{vO}_{2}\right)\right]$. Due to the significant contribution of cardiac output to maximal aerobic capacity ( $\left.\dot{V} \mathrm{O}_{2} \max \right)$, HR also shows a linear relationship with $\dot{V} \mathrm{O}_{2}$ (POOLE \&ERICSON, 2008). This physiological relation can also be applied to submaximal exercise, primarily in the evaluation of the trot and gallop. It is important to note that the cost of a heart rate monitor is markedly lower than a respiratory gas analyzer (i.e., an ergospirometer). In this regard, the relationship between speed and HR is often used to evaluate the athletic potential. Respectively, $\mathrm{V}_{180}$ and $\mathrm{V}_{200}$ represent the speeds at which HR reaches 180 and 200 beats per minute (FERRAZ et al., 2006). Another variable that can be used is $\mathrm{HR}_{\text {peak }}$, the highest heart rate obtained during a session of submaximal exercise. A recent study has used both $\mathrm{V}_{200}$ and $\mathrm{HR}_{\text {peak }}$ to evaluate the training of Arabic and Criolo horses (ALONSO et al., 2013).
Comparing race horses to production animals, such as dairy cows, ROBINSON (2010) noted the need for technical-scientific approach toward the research conducted on race horses, emphasizing the importance of understanding their productivity. In this sense, few authors (FONSECA et al., 2010) have evaluated the influence of DE during training sessions on variables such as physical fitness and racehorses winnings. Thus, the hypothesis tested during this study was that claiming horses that train longer DE, in submaximal exercise sessions with the same mean velocity are more financially productive.

\section{MATERIAL AND METHODS}

During a single training season sixteen claiming Thoroughbred racehorses were followed from September to December of 2009 at the "Jockey Club of São Paulo" hippodrome Brazil, located at latitude $23^{\circ} 34^{\prime} 44^{\prime \prime S}$ and longitude $46^{\circ} 41^{\prime} 54^{\prime \prime} \mathrm{W}$ with an altitude of $1668 \mathrm{~m}$. The horses consisted of ten stallions and six mares with a mean age of 4.5 $\pm 0.98 \mathrm{yrs}$ and a mean body weight of $455 \pm 25 \mathrm{~kg}$. The studied horses participated only in official races that varied from 1000 to $1400 \mathrm{~m}$ in distance; hence they were classified similarly. The horses routinely trained on an oval flat track. All animals were healthy, fully competitive and were submitted to a standard training program that was prescribed by the same trainer and followed workouts that are customary for Brazilian hippodromes. The training program consisted of daily sessions (4-5 times a week) of submaximal exercise; the only difference between them was the exercised distance. It is important to emphasize that the research team did not interfere in the training protocols or general care of the horses, which were the responsibility of the professional team of the Jockey Club of São Paulo.

One training session (prescribed by the coach) per animal was monitored for the purpose of group assignment. Once the distance exercised (DE) was individually determined during this submaximal training session, the horses were distributed into two groups of eight animals each. The short distance (SD) group comprised four females and four males that trained between 1600-1900 m, and the long distance (LD) group comprised two females and six males that trained between $2000-2350 \mathrm{~m}$ on the same sandy track.

The weather conditions remained relatively constant throughout the training sessions with the temperature and relative humidity ranging 
from $22-25^{\circ} \mathrm{C}$ and $40-50 \%$, respectively. The horses were ridden by 3 jockeys chosen by the trainer, with an average weight of $52 \pm 3 \mathrm{~kg}$.

The intensity of each training session was determined by measuring the distance exercised during the training $\left(\mathrm{DE}_{\text {training }}\right)$, the duration of the training sessions $\left(\mathrm{T}_{\text {training }}\right)$, the mean velocity $\left(\mathrm{V}_{\text {mean }}\right)$, the peak velocity $\left(\mathrm{V}_{\text {peak }}\right)$, the distance exercised in official races $\left(\mathrm{DE}_{\text {race }}\right)$ and the difference between the training sessions and official race distances $\left(\mathrm{D}_{\text {training-race }}\right)$. Blood samples were obtained from the jugular vein by venipuncture and collected into sodium fluoride-containing vacuum tubes (BD Vacutainer, Brazil) before the exercise and 1 $\left([\mathrm{LA}]_{1 \text { min }}\right), 5\left([\mathrm{LA}]_{5 \min }\right)$ and $10\left([\mathrm{LA}]_{10 \text { min }}\right)$ minutes after each session.

Blood lactate concentration was measured using an automated analyzer based on the electro-enzymatic method (YSI 2300, Inc., Yellow Springs, OH, USA). Heart rate was determined using a special horse blanket equipped with GPS and a heart rate monitor (E-trakka, Equitronics, Australia), through which the peak heart rate $\left(\mathrm{HR}_{\text {peak }}\right)$ was obtained during training sessions for each experimental group.

It was followed a published criterion that has been previously used for selecting HR/velocity data for the purpose of obtaining a linear regression equation to determine $\mathrm{V}_{180}$ and $\mathrm{V}_{200}$ (velocities where heart rate reaches 180 and $200 \mathrm{bpm}$, respectively). To calculate the best-fit line for the linear regression, all $\mathrm{HR} /$ velocity points with $\mathrm{HR}$ values of $10 \mathrm{bpm}$ or more above the regression curve were removed, as described by GRAMKOW \& EVANS (2006).

The winnings for each horse during a one-year period (2008 to 2009) were obtained on the Brazilian stud book <http://www.studbook. com.br $>$ and the Jockey Club of São Paulo $<$ http:// www.jockeysp.com.br> websites. The prize money in Brazilian currency (R\$) was converted to US dollars (1 USD $=\mathrm{R} \$ 1.70)$. These winnings $(\mathrm{R} \$)$ were correlated with the $\mathrm{HR}_{\text {peak }}$ obtained during the training sessions. All horses completed a minimum of six races in the same category (claiming races).

Statistical analysis was performed using Sigma Plot 11.0. All results were expressed as the mean \pm standard error of the mean (SEM). Normality of the data was determined with the Shapiro-Wilk test. The Student's t-test was used for a non-paired analysis. The association between HR peak and race winnings was examined by calculating the Pearson correlation coefficient and by performing a linear regression analysis. A significance value of $\mathrm{P} \leq 0.05$ was used for all tests.

\section{RESULTS}

The variables $\mathrm{DE}_{\text {training }}$ and $\mathrm{T}_{\text {training }}$ were different between the SD and LD groups, and higher $(\mathrm{P}<0.001)$ for the LD group compared SD group. The $\mathrm{DE}_{\text {race }}$ comparison between the $\mathrm{SD}$ and $\mathrm{LD}$ groups revealed that both groups ran races with distances considered statistically equivalent $(\mathrm{P}=0.586)$. The distances exercised in the trainings session were longer $(\mathrm{P}<0.001)$ than official races distances by $24.7 \%$ and $40 \%$ for SD and LD groups, respectively, and $\mathrm{D}_{\text {training-race }}$ differed between the groups by $47.6 \%$ (Table 1). There was no difference in $\mathrm{V}_{\text {mean }}$ and $\mathrm{V}_{\text {peak }}$. Before exercising [LA] was similar $(\mathrm{P}=$ 0.133 ) between the groups, $0.48 \pm 0.07$ and $0.39 \pm 0.13$ mmol L ${ }^{-1}$ for SD and LD, respectively. Table 2 shows that the $[\mathrm{LA}]$ produced after training sessions was similar between the groups, at all evaluated times. The LD group had a lower HR peak $_{\text {mean values }}(\mathrm{P}=0.005)$. There was no difference in $\mathrm{V}_{180}$ values of both groups. However, $\mathrm{V}_{200}(\mathrm{P}=0.012)$ was significantly different between groups and higher in the group that ran longer distances. Mean of winnings was $58.2 \%$ higher for the LD group compared to the SD group, with total winnings of $\$ 9,470$ and $\$ 5,516$, respectively.

Figure 1 reveals that the correlation between $\mathrm{HR}_{\text {peak }}$ and winnings value was moderate,

Table 1 - Means $( \pm$ SEM) of the distance exercised and the velocity of Thoroughbred racehorses submitted to submaximal training session consisting of smaller distances $(\mathrm{SD}, \mathrm{n}=8)$ or greater distances $(\mathrm{LD}, \mathrm{n}=8)$.

\begin{tabular}{lllllll}
\hline Groups & $\mathrm{DE}_{\text {training }}(\mathrm{m})$ & $\mathrm{T}_{\text {training }}(\mathrm{sec})$ & $\mathrm{DE}_{\text {race }}(\mathrm{m})$ & $\mathrm{D}_{\text {training-race }}(\mathrm{m})$ & $\mathrm{V}_{\text {mean }}\left(\mathrm{m} \mathrm{s}^{-1}\right)$ & $\mathrm{V}_{\text {peak }}\left(\mathrm{m} \mathrm{s}^{-1}\right)$ \\
\hline $\mathrm{SD}$ & $1744 \pm 126$ & $164 \pm 18$ & $1291 \pm 240$ & $431 \pm 171$ & $10.65 \pm 0.7$ \\
$\mathrm{LD}$ & $2263 \pm 68^{*}$ & $211 \pm 12^{*}$ & $1357 \pm 250$ & $906 \pm 245^{*}$ & $10.75 \pm 0.6$ \\
\hline
\end{tabular}

* Indicates statistically higher values between groups based on Student's $t$-test $(P=0.05)$. SD and LD groups trained at distances of 1600 -

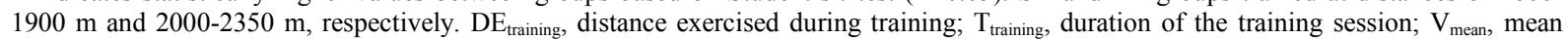
velocity; $\mathrm{V}_{\text {peak }}$, peak velocity; $\mathrm{DE}_{\text {race }}$, distance exercised in official races; $\mathrm{D}_{\text {training-race, }}$ difference in distances exercised between the training sessions and the official races. 
Table 2 - Means $( \pm$ SEM) of lactate concentration, indices of physical fitness and winnings values of Thoroughbred racehorses submitted to submaximal training session consisting of short distance $(\mathrm{SD}, \mathrm{n}=8)$ or long distance $(\mathrm{LD}, \mathrm{n}=8)$.

\begin{tabular}{llllllll}
\hline Groups & {$[\mathrm{LA}]_{\min }$} & {$[\mathrm{LA}]_{5 \min }$} & {$[\mathrm{LA}]_{10 \min }$} & $\mathrm{HR}_{\text {peak }}(\mathrm{bpm})$ & $\mathrm{V}_{180}\left(\mathrm{~m} \mathrm{~s}^{-1}\right)$ & $\mathrm{V}_{200}\left(\mathrm{~m} \mathrm{~s}^{-1}\right)$ & Winnings (USD) \\
\hline SD & $7.00 \pm 3.9$ & $6.26 \pm 4.9$ & $4.69 \pm 3.8$ & $209 \pm 7$ & $7.40 \pm 3.3$ & $10.71 \pm 1.4$ & $689 \pm 190$ \\
$\mathrm{LD}$ & $5.21 \pm 1.2$ & $4.27 \pm 1.6$ & $3.18 \pm 1.7$ & $197 \pm 7^{*}$ & $10.08 \pm 2.6$ & $13.76 \pm 2.3^{*}$ & $1183 \pm 315^{*}$ \\
\hline
\end{tabular}

* Indicates significance between groups based on Student's t-test $(\mathrm{P}=0.05)$. Blood lactate concentrations at 1 ([LA $\left.]_{1 \mathrm{~min}}\right), 5\left([\mathrm{LA}]_{5 \mathrm{~min}}\right)$ and 10 ([LA $]_{10 \mathrm{~min}}$ ) minutes after the end of exercise in $\mathrm{mmol} \mathrm{L}^{-1}$. $\mathrm{HR}_{\text {peak }}$, highest heart rate obtained during the training session; $\mathrm{V}_{200}$ and $\mathrm{V}_{180}$, velocities at which heart rate reached 180 and $200 \mathrm{bpm}$, respectively.

although not significant $(\mathrm{r}=-0.42 ; \mathrm{P}=0.101)$ and the coefficient of determination from the regression analysis was 0.18 .

\section{DISCUSSION}

This research study was possible due to considerable advancements and increased availability of technologies that enable field studies, especially the GPS technology (FONSECA et al., 2010). GPS has been essential for obtaining the measurements needed to assess physical fitness, such as the speeds and distances achieved under actual environmental conditions.
According to the classification of exercise proposed by EVANS (2000), the training sessions of horses in this study could be classified as "vigorous" because they reached velocities greater than $10 \mathrm{~m} \mathrm{~s}^{-1}$ and lactatemia after exercise ranged between 4 and $8 \mathrm{mmol} \mathrm{L}^{-1}$. During exercise, lactate increases in the blood stream once the production exceeds its utilization and elimination (FERRAZ et al., 2008). The lactatemia observed in the present study was lower than the concentration found by MUKAI et al. (2007), who evaluated exercise intensity in simulated races of $1200 \mathrm{~m}$ on a sandy track with mean velocities of $15 \mathrm{~m} \mathrm{~s}^{-1}$ and lactatemia of $22.5 \pm 0.6 \mathrm{mmol} \mathrm{L}^{-1}$.

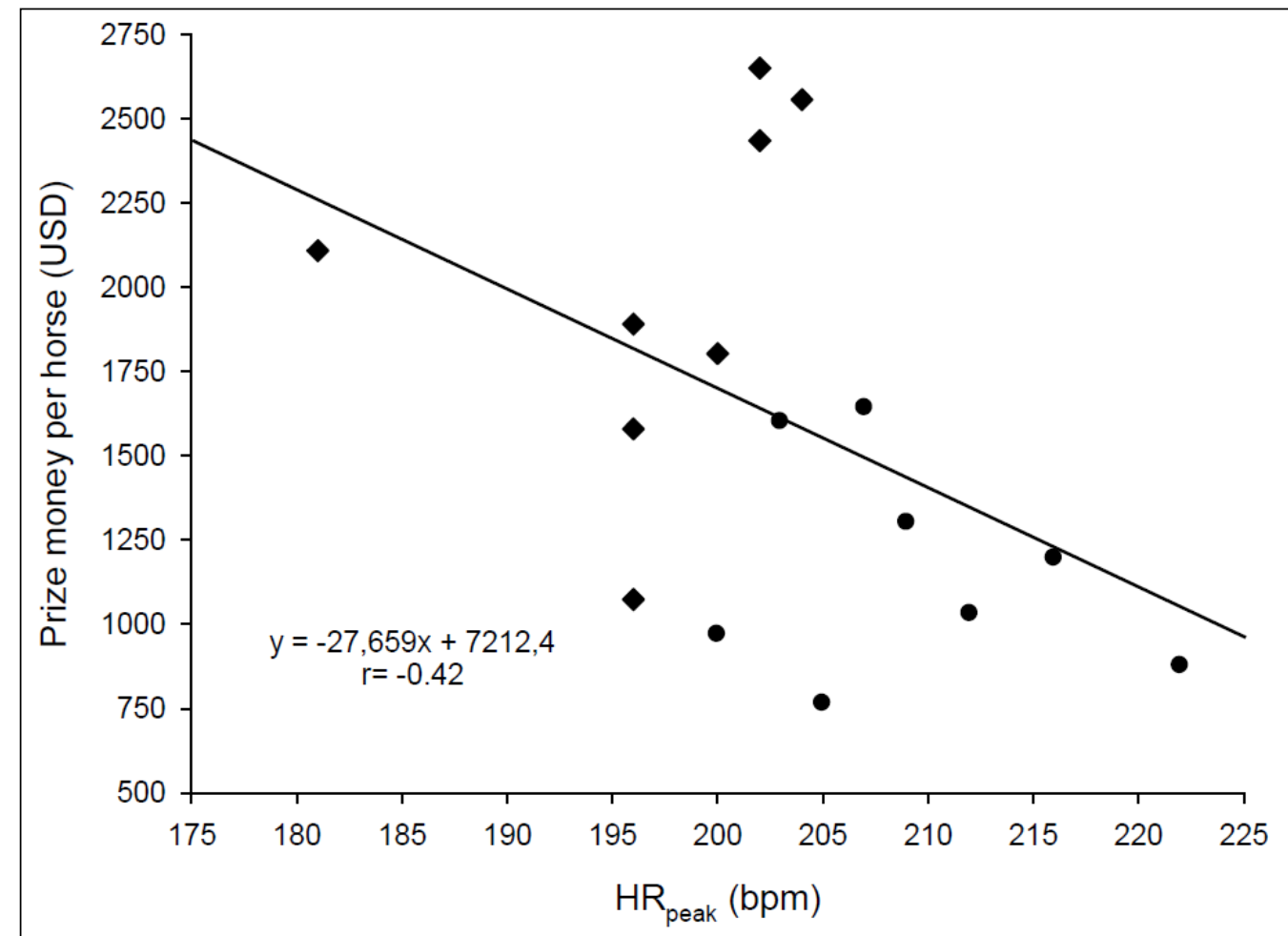

Figure 1 - Peak heart rates attained during the gallop in relation to the race winnings values of both groups. Short distances (SD) group $(\bullet)$ and long distances (LD) group $(\bullet)$. 
This result occurred because, in a race simulation, the exercise intensity is maximal and significantly greater than in a submaximal training session. Thus, it appears that velocity is the principal exogenous stimulus for anaerobic production of ATP, which can be inferred from the increased production of lactate. Similarly to the present study, CYWINSKA et al. (2011) reported that race horses subjected to submaximal exercise had lactatemia between 3.86 to $6.68 \mathrm{mmol} \mathrm{L}^{-1}$. Some intrinsic factors can interfere with the lactate production, such as the removal capacity related to the total muscle mass, extent of local blood flow, quantity of capillaries, oxidative capacity of active and inactive muscles, and the level of gluconeogenesis (SIMÕES et al., 1999; FERRAZ et al., 2008).

In the present study, Thoroughbreds (LD group) that raced from 1000 to $1400 \mathrm{~m}$ trained at submaximal effort for $22 \%$ longer distances. The incipient results showed that lower submaximal heart rates during training sessions correlated with higher payouts from races during an one-year period. For sure, the validity of this conclusion is limited by the fact that other factors, both extrinsic such as the weather, different stages of fitness, track condition, the jockey, and the shoeing, as well as intrinsic, such as the history of injuries, subclinical pathologies, and athletic condition, may also influence the races results.

Regarding the distance exercised, the horses of the LD group ran on average 3,624 more meters per training week than those of the SD group. This suggests that the greater distance exercised can contribute to submaximal cardiac adaptation, which was reflected in the greater winnings of LD group. The distance exercised is a little studied variable (FONSECA et al., 2010) in experimental models that focus on the ideal prescribed training for horses. Although there was no mention of the study reported by OHMURA et al. (2002), these authors demonstrated an improvement in $\mathrm{V}_{200}$ in Thoroughbred colts subjected to submaximal training, when mean distances increased by 37.5 to $41 \%$ during a monitored training program. Our results showed that horses in the LD group had better submaximal physiological indices, including a higher $\mathrm{V}_{200}$. This suggests that exercising at greater mean distances while maintaining the same intensity (mean velocity) can contribute to improved athletic fitness.

Despite its limitations, this is the first study to correlate training of an experimental sample of Brazilian racehorses at submaximal heart rate conditions $\left(\mathrm{HR}_{\text {peak }}\right)$ with their retrospective financial performance. The correlation was moderate, although not significant, with a coefficient of determination of only $18 \%$. Various factors can contribute to this result, such as the relative contributions of the aerobic and anaerobic metabolic pathways during exercise, gathering data during routine training sessions without exercise standardization, and the subjective classification of the horses by the trainer (GRAMKOW \&EVANS 2006). Additionally, the classification of the horses into either the SD or LD group was based on the historical records of the trainer, which did not consider factors such as the gallop conditions, the jockey's ability and the intensity of the sessions that mimicked the official race. This consideration is in agreement with the study of FONSECA et al. (2010), who noted the necessity to control these variables in studies focusing on performance results.

The LD group amassed more prize money. This finding suggests that the competitiveness of a racehorse is related to its training load, which in this study was represented by longer distances. From a practical point of view, the trainers crowded in Brazilian hippodromes generally use relatively short training sessions, with velocities of approximately $12.5 \mathrm{~m} \mathrm{~s}^{-1}$. However, the data obtained in this study indicate that increasing the length of submaximal training sessions can increase the athletic capacity of the horses. Nevertheless, a change to this type of training program would require financial rearrangements due to the increase in operational costs, primarily due to increased labor costs during the extended training sessions. However, these higher costs could be recovered from the increased productivity of the horses during official races.

It should be mentioned that racehorse training in Brazil is sometimes carried out in a nonindividualized manner with very subjective criteria, similar to other regions of the world (ROGERS et al., 2007). In Brazil, the main reason for this is that owners and horse-training professionals have lack of basic knowledge about the physiology of equine athletes, but also due cultural reasons and restricted access to academic knowledge and advancements. Thus, the academic circle should aim to improve its disclosure to trainers and veterinarians. Surely, the modernization of training through the use of GPS technology would increase the productivity of racehorses, an essential aspect mentioned by ROBINSON (2010).

Based on the results of the performance variables obtained from this study, it was concluded that submaximal training with greater volume and distances exercised may have a tendency to 
increase the financial productivity of racehorses. In any case, these results are expanding our growing knowledge on the subject.

\section{ETHICS COMMITTEE}

This study followed the Ethical Principles in Anima Experimentation adopted by the Brazilian College of Animal Experimentation and was approved by the institutional animal careand use committee of the university (CEUA 8481/11)

\section{ACKNOWLEDGMENTS}

Supported by Fundação de Amparo à Pesquisa do Estado de São Paulo (FAPESP) (2007/08671-0). The author wish to thank the staff of the Equine Center (Jockey Club de São Paulo Rua Bento Frias, 248 - Grupo 39, CEP: 05423-050) for their support in conducting this study.

\section{REFERENCES}

ALONSO, J.M. et al. O treinamento nos valores da $\mathrm{V}_{200}, \mathrm{FC}_{\text {pico }}$ e distância percorrida de cavalos da raça Árabe e Crioula. Ciência Rural, v.43, n.4, p.722-728, 2013. Available from: <http://www. scielo.br/pdf/cr/2013nahead/a11713cr6842.pdf > . Acessed: jan, 18, 2014. doi: 10.1590/s0103-84782013005000025.

CYWINSKA, A. et al. Gender differences in exercise - induced intravascular haemolysis during race training in thoroughbred horses. Research in Veterinary Science, v.90, p.133137, 2011. Available from: <http://www.ncbi.nlm.nih.gov/ pubmed/20553886>. Accessed: dec, 01, 2013. doi: 10.1016/j. rvsc.2010.05.004.

EVANS, D.L. Training and fitness in athletic horses. Queensland: Rural Industries Research and Development Corporation, 2000, 64p. Available from: <https://rirdc.infoservices.com.au/ items/00-001>. Accessed: jun, 24, 2010. ISBN: 0-642-58031-6.

EVANS, D.L. Physiology of equine performance and associated tests of function. Equine Veterinary Journal, v.39, p.373383, 2007. Available from: <http://www.ncbi.nlm.nih.gov/ pubmed/17722733>. Accessed: dec, 01, 2013. PMID: 17722733.

FERRAZ, G.C. et al. Long-term creatine supplementation improves the aerobic capacity of horses. Ciência Rural, v.36, n.2, p.514-519, 2006. Available from: <http:/www.scielo.br/ scielo.php?pid $=$ S0103-84782006000200023\&script $=$ sci arttext $>$. Accessed: dec, 01,2013. doi: 10.1590/S0103-84782006000200023.

FERRAZ, G.C. Blood lactate threshold reflects glucose responses in horses submitted to incremental exercise test. Arquivo Brasileiro de Medicina Veterinária e Zootecnia, v.60, p.256-259, 2008. Available from: <http://www.scielo.br/scielo.php?script=sci artt ext\&pid=S0102-09352008000100035>. Accessed: dec, 03, 2013. doi: 10.1590/S0102-09352008000100035.
FONSECA, R.G. et al. The association of various speed indices to training responses in Thoroughbred flat racehorses measured with a global positioning and heart rate monitoring system. Equine Veterinary Journal, v.42, suppl.38, p.51-57, 2010. Available from: <http://onlinelibrary.wiley.com/doi/10.1111/ j.2042-3306.2010.00272.x/abstract $>$. Accessed: jan, 03, 2013. doi: 10.1111/j.2042-3306.2010.00272.x.

GRAMKOW, H.L.; EVANS, D.L. Correlation of race earnings with velocity at maximal heart rate during a field exercise test in thoroughbred racehorses. Equine Veterinary Journal, v.42, suppl.36, p.118-122, 2006. Available from: <http://www.ncbi. nlm.nih.gov/pubmed/17402405>. Accessed: feb, 02, 2013. PMID: 17402405 .

MUKAI, K.et al. Heart rates and blood lactate response in Thoroughbred horses during a race. Journal Equine Science, v.18, n.4, p.153-160, 2007. Available from: <http://www.researchgate. net/profile/Kazutaka_Mukai/publication/248394785_Heart Rates and Blood Lactate Response in Thoroughbred Horses_during_a_Race/links/02e7e51df6a5 $\bar{c}$ cd886d000000.pdf $>$. Accessed: feb, 02, 2013.

OHMURA, H.et al. Changes in running velocity at heart rate 200 beats $/$ min $\left(\mathrm{V}_{200}\right)$ in young Thoroughbred horses undergoing conventional endurance training. Equine Veterinary Journal, v.34, p.634-635, 2002. Available from: <http://onlinelibrary.wiley. com/doi/10.2746/042516402776180142/abstract>. Accessed: jan, 15, 2013. doi: 10.2746/042516402776180142.

POOLE, D.C.; ERICKSON, H.H. Cardiovascular function and oxygen transport: responses to exercise and training. In: HINCHCLIFF, K.W.et al. Equine exercise physiology: the science of exercise in the athletic horse, Philadelphia: Saunders, 2008. p.212-245.

ROBINSON, N.E. The racehorse and the dairy cow: A question of productivity. Veterinary Journal, v.184, p.251-252, 2010. Available from: <http://www.ncbi.nlm.nih.gov/pubmed/19703782>. Accessed: jun, 10, 2014. doi: 10.1016/j.tvjl.2009.06.023.

ROGERS, C.W. Describing workload and scientific information on conditioning horses. Equine Comparative Exercise Physiology, v.4,p.1-6,2007. Availablefrom: $<$ http://www.wageningenacademic. com/_clientfiles/CEP/S1478061507727408a.pdf>. Accessed: dec, 15, 2011. doi: 10.1017/S1478061507727408.

SIMÕES, H.G.et al. Blood glucose responses in humans mirror lactate responses for individual anaerobic threshold and for lactate minimum in track tests. European journal of applied physiology and occupational physiology, v.80, n.1, p.34-40, 1999. Available from: <http://www.ncbi.nlm.nih.gov/pubmed/10367721>. Accessed: jul, 23, 2011. PMID: 10367721

VERMEULEN, A.D.; EVANS, D.L. Measurements of fitness in Thoroughbred raceshorses using field studies of heart rate and velocity with a global positioning system. Equine Veterinary Journal, v.36, p.113-127, 2006. Accessed from: <http://www.ncbi. nlm.nih.gov/pubmed/17402404>. Accessed: jan, 14, 2013. PMID: 17402404. 